WellBeing International

WBI Studies Repository

1985

\title{
Is Man's Infliction of Suffering on Animals Immoral?
}

Robert Welborn

Follow this and additional works at: https://www.wellbeingintlstudiesrepository.org/acwp_sata

Part of the Animal Studies Commons, Ethics and Political Philosophy Commons, and the Other Anthropology Commons

\section{Recommended Citation}

Welborn, R. (1985). Is man's infliction of suffering on animals immoral?. In M.W. Fox \& L.D. Mickley (Eds.), Advances in animal welfare science 1985/86 (pp. 297-302). Washington, DC: The Humane Society of the United States.

This material is brought to you for free and open access by WellBeing International. It has been accepted for inclusion by an authorized administrator of the WBI Studies Repository. For more information, please contact wbisr-info@wellbeingintl.org.

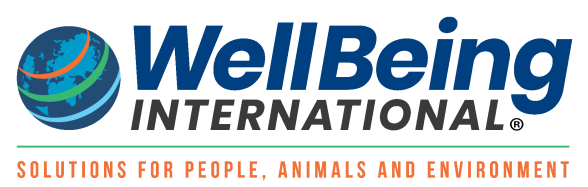




\section{IS MAN'S INFLICTION OF SUFFERING ON ANIMALS IMMORAL?}

\section{Robert Welborn}

P.O. Box 208

Franktown, Colorado 80116

Must not the first step in the consideration of this question be definition: what is moral? Webster's Dictionary says it is that which is "conforming to generally accepted ideas of what is right and just in human conduct" but let us propose another definition: that conduct which is compassionate, rational, and vital in relation to the preservation and enhancement of life itself.

If it is believed that man is properly in dominion over the earth and that he may do with it and all things on it as he will, then the first definition is sufficient. If generally accepted ideas in man's community are to the effect that man's infliction of suffering on animals is right, then such is not immoral.

If it is believed, however, that life, all life, as it has evolved in its beauty and complexity is the consideration upon which conduct should be judged, then the second definition must apply. Man being the dominant species that consciously and by plan produces suffering or harmony, beauty or ugliness, can do or fail to do what is right in relation to all life. Of course the first definition does not rule out ideas for human conduct that are determined in relation to life but it does not require such ideas.

If a person should put a dog in a cage and then abandon it to die slowly for want of food and water, it would be said that such conduct is immoral under both the first and second definitions. If, however, a person in a white coat for experimental purposes injects lye into the esophagus of a $\operatorname{dog}$ and the $\operatorname{dog}$ experiences pain and loneliness for days or weeks before death, it would be said by many that this is moral 
under the first definition because it is generally accepted that animals should be used in laboratories for the benefit of mankind. (This usage of dogs and many other horrendously cruel usages of animals are reported in authentic detail by Dallas Pratt M.D. in his books: Alternatives to Pain in Experiments on Animals and Painful Experiments on Animals. Anyone wanting to know what life is really like on this globe under man's dominion should read these books.) But this type of laboratory use is immoral without question under the second definition. It is the infliction of prolonged unnatural suffering on a sentient creature, an abuse of life.

The world and life on it, including man's life, will be secure from extinction and life will be profoundly satisfying only when the first and second definitions mean the same thing, when man fulfills his dominant and self-conscious part in the life process with compassion, reason, and vitality. Those who are concerned with animal welfare must strive toward the merging of the definitions so that the second is really a part of the first, must be imbued not just with the horror of man's cruelty to other living things but with the reverence for all life, its evolution and its beauty.

One approach to this merging of the definitions is to teach, and hopefully bring people to the realization, that humanity's welfare is intertwined with the welfare of all life on this earth. This certainly is an approach that should be followed but it suggests an acceptance of the first definition alone with man's welfare still being the sole consideration and with man, although broadening his purview, still determining what life serves his purpose and what does not. This selective evaluation would seemingly permit whatever action man conceived to be in his own self-interest with other life being subservient to it. The goal is the unity of human self-interest and the interest of all life. When this goal is achieved, and thus people revere all life as they revere their own part, there will be a merging of the definitions. (See Mary MidgleyAnimals and Why They Matter, 1984, University of Georgia Press, for further fine discussion.)

The other approach to the merging is to seek moral propriety outside of man. It seems fundamental that if there is no value determinant outside of man, if there is no God, then morals are a matter of the dominant expediency. (Thomas Jefferson invoked the Laws of Nature and Nature's God to establish the values, life, liberty and the pursuit of happiness, as against the temporal expediency that was dominant.) We can urge that it is expedient for people to realize that their welfare and the welfare of all life are interdependent. But expediency is a vagrant thing. It varies according to the situation; it is not the same from one society to the other, from one generation to the next. It simply teaches that that which seems to work in a particular society will be the determinant of the morals of that society. Assault and battery will be 
punished because it is inimical to the peace and comfort of the society. The torment of animals in laboratories, in entertainment spectacles, and in food production procedures will not be punished because it is felt that these uses of animals contribute to the pleasure and comfort of the society, such being a proper test of propriety and morals. There are no universal, permanent values, only values for a particular time and place.

It is, therefore, only with a consideration outside of man that universal values are found, the second definition made universally applicable and the merger of the two definitions made secure. This consideration is God and God is manifest in the life that has evolved on this earth. God is not supernatural or mystical but the essence of the natural, the truth of the universe and the truth of the meadowlark and the blade of grass. This is not the god of any particular religion or cult. No confined doctrine or teaching of any sect can lay claim to God-only life itself and man as a part of that life.

The truth that is God is all encompassing. There is no separation of fact and value; there is no distinction between science and compassion and no isolation of science from the moral sphere. Each element of reality, each element of life, the seen and the unseen, the known and the felt, the proved and the believed, is involved in and is a part of those values which are consummate in beauty. This is the purpose, the harmony and the balance, and includes the minutest part of life and each particle that makes up the sunset and the sea.

Man's anthropocentrism is nowhere more evident than in the gods he chooses and thus those gods are basically called upon to have as their primary concern the salvation of man. Man mostly conceives that he alone of the species has a soul worthy of consideration by a divine being. There is no realization that man's function is fulfilled and happiness achieved by serving God and that this can only be done by serving life and beauty which are the manifestation of God. This service calls for the second definition.

People shy away when one talks about God as the universal being not defined by a particular doctrine. They cannot stand the broad responsibility and seeming uncertainty of service to God through the preservation and enhancement of life, through the inspired and rational creative process of love for that life. They want their book to tell them what to do. They seek refuge from the discomfort either in the dogma of some organized religion which teaches the propriety of man's dominion or in the dominion itself which they assume justifies all, without God.

Acceptance of the second definition is the real hope for the cause of animal welfare, for the reduction and elimination of the suffering which man inflicts on other living things. Although there may seem to be more people aware of this suffering, the massive obstacle of indifference 
enlarges and the number of animals used and abused each year increases. Without a new and true morality people will continue with their approval of the torture of rabbits, monkeys and calves for the benefit of cosmetics, science, good food and entertainment.*

The truth that people fail to grasp is that only by respecting and serving all life for its own sake will they achieve for themselves meaningful and satisfying lives. The callous and irrational preoccupation with the use of all other things on this earth, animate and inanimate, for present and often perverted physical comfort and gratification portends certain deterioration. Man fails even to protect his own progeny by conservation and the reasonable use of natural resources, and fails to realize the happiness that would come from a compassionate and rational relationship with other forms of life.

Several years ago Mortimer Adler of the Great Books program discussed the arguments of the humanists as against those he called animalists. The humanists, he said, take the position that animals do not have inherent dignity or inherent rights but that people might do moral damage to themselves by being cruel to animals, (The Great Ideas Today - 1975, Encyclopaedia Britannica, Inc.). There is no felt or understood awareness of the sanctity of all life, of the capacity of the dog or bird for pain or love or joy. Man, the tormentor and destroyer, is the only important thing. These humanists never saw or found the dignity of the cow with her calf, the hen with her chicks, the mother gorilla with her baby. Under their theory the covert torment of animals in laboratories would be acceptable because no one but the attendants and experimenters sees the animals, society is not exposed to the atrocities and thus the human race does not suffer moral damage. The attendants and experimenters are indifferent to the suffering of the animals and therefore the cruelty has no affect on them.

A contrast to this failure to understand and be inspired by the significance of all life is the thought and feeling of Loren Eiseley who had the completeness of perception to believe and know that all life is sacred, from the vagrant seed drifting in the air to the violet and the tree frog. He spoke from the expertise of his profession, anthropology, and with the sensitivity of an Emily Dickinson. From personal experience he told of the capacity of the hawk and the fox for pain and love and joy. For him there was companionship and familial oneness with this hawk and this fox and with the bittern in whose life there was a fundamental element like an element in his own. (See Loren Eiseley's

\footnotetext{
*This is a reference to the United States government-sanctioned Draize test in which the substance to be tested is placed in the eye of a live conscious rabbit to see how long it takes to cause irreparable damage to the eye; to the misery of primates restrained in vice-like chairs for endless days of psychological or surgical experiments; to the confinement of veal calves in boxes; and to the brutal torment of calves and steers in roping contests at rodeos or practice arenas.
} 
The Star Thrower, a collection of essays and Another Kind of Autumn, a collection of poems.)

The insensitive rationalization that only man has dignity or rights underlies the first definition and that definition is predominant. How then do we effectively invoke morality in our presentations to those people who could do something for animal welfare - by legislation, by teaching, or by direct action? We unequivocally assert the second definition. We sustain it affirmatively by the perception of people of science such as Loren Eiseley. We sustain it negatively by the teaching of authorities such as Jonathan Schell and Paul and Anne Ehrlich. (Jonathan Schell's Reflections on The Fate of the Earth received wide recognition when they first appeared in The New Yorker in 1982. The Ehrlichs' book entitled Extinction deals with just that.) This is the perception and this is the teaching that man may well be in the process of ending life on this earth, either abruptly or gradually.

Some may question the relevance of this reference to the extinction of life in a paper dealing with the subject of animal welfare. It may be said that man can determine what life forms continue and what do not and that whether or not living things suffer at the hands of man is irrelevant to the question of survival. But this is precisely the danger-man's assumption that he can be the determinant of life. Man has failed completely in this regard and this establishes that only a respect for all life will unify humanity and carry it through the destructive forces it has created. This respect is the basis for the second definition, a moral standard existing outside of man. One cannot respect life and permit its torment. This is fundamental. The infliction of suffering is by definition immoral.

Let us not hesitate to urge this morality on all persons to whom supplication is made for animal welfare. There will be deaf ears and bored expressions but this is our only hope for man's proper relationship with animals and for the balance and development of life itself. Unless the humane treatment of animals is made a part of the most basic and affirmative moral considerations, it will continue to be treated by the lawmakers and the teachers and by society in general as a minor matter in relation to what man conceives to be his major concerns and desires.

Through the process of evolution and refinement man has come to have the capacity for compassion and reason, the two attributes that must be constantly combined, and to have the power of domination. This capacity and this power make possible the responsible custodianship of the earth and all life on it. If the capacity is unused, the power becomes the devolutionary force it is today and all life suffers.

What are the responsibilities of this custodianship? They are to conserve and nurture the earth's natural resources, the minerals, the vegetation, the soils, the contours, the air and the water so that they are an ever-present source of life and beauty; and they are to protect and care for those animals that are under or affected by man's dominion 
so that they will have lives no less vital than in natural conditions with suffering minimized as much as humanly possible.

Suffering is a fact of life. Man cannot eliminate it for himself or for other creatures. But the suffering imposed by man on other living things is different in kind from the suffering of animals in nature. With man animals are in an alien world; with nature they are in their own environment. Man need not and should not interfere with the natural environment, even in an attempt to alleviate natural suffering. His function is to deal with the suffering he creates. This he can control and prevent.

The moral charge to man is to have the same fervor and diligence for the preclusion of animal suffering that he has for the preclusion of his own. The implementation of this charge must be accomplished by laws and standards as detailed as those man has conceived for his own governance, realizing that different laws and standards would be appropriate in many respects for different species or different conditions of particular animals. For example, these laws or standards would require that laboratory animals live in comfortable, non-stressful conditions and be protected from pain by anesthetics, analgesics or other appropriate care, with the elimination of the use of animals in laboratories as the ultimate requirement; they would deal with the care and humane raising, handling, transportation, and slaughter of animals used for food; and they would preclude the use of animals for or in connection with entertainment if such use would cause stress or pain.

Surely all of this responsibility involves something very affirmative, not the passive approach of those who feel only that cruelty to animals might be bad for human morals nor the approach that relies on sensitizing people and making them feel uncomfortable about cruelty, however commendable such an approach might be. This affirmative responsibility involves man leading himself into the inspired, rational, and vital state of being in which there is respect, and indeed reverence, for all life with man's life being relevant as a part of the whole. Only this completely positive way will preclude extinction and bring balance, harmony, and constructive relationships among all living things. This then is the morality, some may call it religion, for animal welfare because it is the morality for all life, including man's.

Perhaps those professors of human and divine morality who speak from temple and mosque, from synagogue and church could be persuaded that all life is involved in the constitution of morality and in morality's purview and protection. Perhaps those people who are moved to tears by Bach's great Saint Matthew Passion as it profoundly sings of the suffering of a great human being can be moved to tears by the suffering of the dog and the calf as they are tormented by human cruelty. Because this is the hope: the uniting and the unity of those passions which make up the religious, the music and the humanitarian experience in compassion for life itself. 